\title{
Preliminary Design for Implementation of the "Education Voucher" System in Vocational Education
}

\author{
Zheng Ma \\ Tianjin Vocational Institute \\ Tianjin, China
}

\begin{abstract}
In recent years, the vocational education in China has got rapid development, and has achieved considerable educational achievements. However, it should be noted that the vocational education in China still faces the following problems: insufficient financial funds, low economic capacity of student's family, and educational achievements which are insufficient to support the demand for vocational education. It also requires that managers must use new and more effective resource allocation policy of vocational education to guide, encourage, and foster vocational education schools and students, so as to play the role of vocational education in promoting the development of society and economy. From the perspective of institutional design, this paper analyzes the necessity and feasibility of "education voucher" system in the field of vocational education. It expounds the difference between the implementation of the education voucher system in the field of vocational education and the area of basic education and foreign higher education in the past, and also proposes the preliminary design of the implementation of the education voucher system in the field of vocational education in the hope of solving many problems in the field of vocational education.
\end{abstract}

Keywords-education voucher; vocational education; institutional design

\section{INTRODUCTION}

In recent years, the vocational education in China has presented a leapfrog development. Higher education has gained more and more social recognition, and the number of school enrollments and graduate's entry salary has also gradually increased. However, we should also be aware that some of acute problems in vocational education in China have not been effectively resolved, and the most typical one is the contradiction between supply and demand in vocational education. It shows as follows: on the one hand, it includes the administrative division of the existing vocational education, consistency of school system, and increasing educational expenses; on the other hand, a considerable part of students in vocational education are under great financial pressure, and at the same time, students cannot establish the achievement goal of vocational education because they have no work experience. These contradictions in the two aspects have caused that the economic pressures of students' family increases, they lack good initiative of learning, and the effects of vocational education are poor when they enter higher vocational education. This paper intends to draw lessons from the education voucher system initiated by the United States, combines its public welfare and the characteristics of vocational education in China, and initially designs the education voucher system applicable to vocational education in China, so as to provide an operational idea to solve the contradiction between supply and demand in the existing vocational education.

\section{OVERVIEW OF THE “EDUCATION VOUCHER” SYSTEM}

In recent years, the vocational education in China has changed from the reform of education mode to the improvement of education quality. However, the development of vocational education in China cannot reach the level of development of vocational education in developed countries; therefore, it cannot provide sufficient support for socio-economic development and lack adequate contribution to the solutions of labor demand. The reason is that the vocational education in China still faces many institutional obstacles and problems. The specific performance is as follows:

\section{A. The Level of School-running Is Low and Social Influence Is Weak}

In general, vocational education at all levels in China is lower than the education in similar academic education It is difficult for students in secondary vocational education to get jobs. Most of students cannot enter the society, and they further study for higher vocational education or academic education, and the professionalism of secondary vocational education cannot be reflected. Higher vocational education has an educational background but no degree provided, therefore, parents and students generally do not approve highly of it. Quite a number of students enter the channel that the university is upgraded from college, and students who choose to work are less competitive because of their educational background and degree.

CLC No.: G648.7 Document code: $\mathrm{B}$. 


\section{B. The Government's Support Policy Is Not Strong, and Capital Investment Is Insufficient}

The vocational education at all levels faces the problems that the policies have not been implemented, such as land use indicators, reasonable returns, teacher establishment, enrollment level, financial support, risk prevention, and so on, resulting in that the per-capita education spending of vocational education students at all levels is significantly lower than that of academic education the same level generally. The annual average budget of vocational education institutions is also generally lower than that of academic education institutions.

\section{Students in Vocational Education Generally Have Poor Economic Strength}

At present, a considerable part of students at all levels of vocational education in China come from poor families or areas with poor economic conditions. Students' willingness to make a living or to be financially independent is quite urgent. The economic burden for students' family that vocational education investment has caused for several years cannot be ignored. Although the state and local governments have also issued scholarships and grants policy, the coverage is low and cannot meet the diverse needs of students.

In the face of the problems above, to promote the fair development of vocational education and further enhance the attractiveness of vocational education to students and parents, we try to adopt a new incentive system in terms of policy, which is of great strategic significance to the long-term development of vocational education in China.

The "education voucher" is also known as "school voucher". Its basic idea is to change the educational input way in which the government subsidizes public schools directly. After the education funds directly invested in public schools in the past are converted based on unit cost of per capita, they will be directly distributed to students or families in the form of securities (that is, education voucher) with fixed denomination. Students can enter any governmentapproved college by means of the education voucher, and the voucher can offset all or part of the tuition fee, and colleges can use educational vouchers to exchange educational funds with government departments. At present, the education voucher system used in countries around the world can be divided into two modes. One is the "non-wealth exclusion" mode, which means that all children of school age can get the education voucher with the same face value. Parents can freely choose schools in different charging standards, and the insufficient part will be paid by them, so as to promote a free education market. The theory of educational vouchers of Friedman belongs to the former. The other is the "wealth exclusion" mode, which believes that the former model does not truly embody the principle of social equity and advocates giving special subsidies to low-income people or families with special needs. The mode of compensation voucher proposed by Jencks belongs to this mode. The education voucher system implemented in Changxing County of China also is inclined to this model.
The education voucher of vocational education proposed in this paper, based on the "non-wealth exclusion" mode, includes the admission right of vocational education, that is, vocational education admission certificate + education subsidy. First of all, vocational education has a fundamental feature of long term, which differs from that students have a fixed and relatively continuous period of education and age in academic education. The requirements of vocational education often come from the professional experience of students, and the professional experience of students often reflects the migration of region and discontinuity of time. Next, from the perspective of the overall economic affordability of the students' families that choose vocational education and government's strategy for developing vocational education, this kind of education subsidy fund investment is universal and aimed at all education audiences. Therefore, in the case of a single source channel and shortage of vocational education funds, the education vouchers of vocational education in China include the subsidy effect of traditional education vouchers and the proof of admission qualifications.

\section{THE CHARACTERISTICS AND NECESSITIES OF "EDUCATION VOUCHER" SYSTEM IN VOCATIONAL EDUCATION}

In terms of the three major problems of vocational education in China mentioned in the previous section, the first problem of school-running level depends on the government's overall change in the vocational education system, so it is beyond the scope of this article. However, the education voucher system is conducive to solving the latter two problems.

First, the education voucher system in this paper is different from the traditional voucher system. No matter what kind of traditional education voucher system is, it represents that the government directly grants students a certain subsidy, and has the property of voucher. The vocational education voucher in this paper does not have the nature of subsidizing student individual, but is only a necessary proof of the actual number of students enrolled in higher vocational colleges. Higher vocational colleges obtain education funds and subsidies from higher-level management institutions and financial institutions based on the number of education vouchers collected in the same year, that is, the number of education vouchers collected by higher vocational colleges is the actual number of students enrollment in the college's plan. Therefore, the education voucher system proposed in this paper does not involve the scope of grants or scholarships granted by the government to students.

Second, apart from giving vocational education institutions and students subsidy funds on behalf of the government, the education voucher also represents that students have the right to accept higher vocational education. Vocational education itself covers the education needs of student' career in multi stages, so students with education vouchers can flexibly choose the admission date and learning stage of higher vocational education. This will produce a result that when the economy develops well, students tend to 
be employed, and the education vouchers are used sparingly, and the government has little pressure on the financial allocation of vocational education. During the economic downturn, students tend to receive vocational education, and the use of education vouchers increases, and the government should increase investment in education and stimulate the economy.

Next, students with education vouchers can flexibly make a choice between receiving vocational education or advance employment without affecting their enjoyment of government education subsidies, which can alleviate the financial burden of students with poor family. Students find a job first and get paid, and they recognize the importance of accepting higher vocational education in the process of work, and increase their interest and motivation in acquiring higher vocational education. When entering the stage of higher vocational education, they not only have certain financial conditions accumulated in the working stage, but also can enjoy the government's financial subsidies, and has the motivation and direction of learning at the same time, which is conductive to improving the efficiency of vocational education, changing the current situation of poor vocational education teaching, and transforming the status quo of higher vocational education from the demand side.

In short, the application of education voucher system can provide students with a certain selection space without increasing the economic burden of the government, colleges, and students. Students can flexibly make a choice between further study and employment based on their economic conditions and own interests. Meanwhile, the education voucher is bound to the student individual and cannot be used for trading. Students cannot directly receive the subsidy, but the voucher can be transferred with the student's career choice. That is to say, the education voucher will be issued at the origin of students, and students can choose to use the education voucher at the workplace. This will not only promote the free flow of the working population, but also accelerate the process of urbanization in China. At the same time, it will encourage different vocational colleges to improve their teaching quality in the system, and attract students to use educational vouchers in this college. Finally, the essence of the education voucher is the student education account, and it is not difficult to technically implement at all, so this system is completely feasible.

From the perspective of necessity, the application of the voucher system to vocational education can achieve the following effects:

\section{A. Improving the Financial Efficiency of Higher Vocational Education}

In 2016, the total investment in higher vocational education was 182.8 billion yuan, but obviously, the waste and performance of public education resources was not clear. In terms of the implementation of education voucher system, from the view of government, we will introduce the investment decision that guides students to participate in education in the case that the total planned investment amount remains unchanged. From the view of college, the "seller market" of education has changed into the "buyer market". Students who choose their own college based on their own wishes and professional need voucher, which can promote a benign competition between higher vocational education colleges. Colleges must strengthen their own construction and improve the quality of running schools to maintain the attraction and competitiveness to students and parents. Meanwhile, even for the purpose of advertising, vocational education colleges will also increase publicity for their own college-running conditions and levels, which also exposes the operation of higher vocational education colleges to the supervision of the society. A group of formerly public and low quality colleges will be naturally eliminated, and they will no longer occupy scarce state educational funds.

\section{B. Promoting the Industrial Concentration of Higher Vocational Education}

According to Statistics Bulletin on the Implementation of National Education Funds in 2016, it can be shown that although the total amount of public finance education investment is increasing, the per capita funding is still weak. In particular, the per capita funding in higher vocational education is relatively low. The experience of the world's vocational education powerhouse is to vigorously develop private vocational education in the industry and attract more private capital and social forces. Encouraged by the education voucher system, in order to increase the number of students receiving education vouchers, the powerful colleges of higher vocational education will inevitably try many ways to mobilize more private capital to invest in education, and continuously expand and merge with the backward higher vocational education colleges, so as to reduce the industry cost, improve the efficiency of the industry, and alleviate the awkward situation of low efficiency of higher vocational education in China.

\section{Improving Students' Autonomy in College Selection}

The education voucher gives the students the right to choose schools. They can not only choose the corresponding higher vocational colleges with high level in the origin of students, but also use the education voucher to select the higher vocational colleges which conform to conditions of their working place. At the same time, the vouchers can only be used for education, act as a vocational education subsidy based on the policy when they enter school, and cannot be used for other purposes. In this way, the value of education voucher will not be depreciated due to economic factors such as inflation, and will not be changed into cash by the owner for profit. It better guarantees the right of students from poor families to receive higher education.

\section{PRELIMINARY DESIGN OF IMPLEMENTING THE "EDUCATION VOUCHER" SYSTEM IN VOCATIONAL EDUCATION}

\section{A. Distribution Range}

The distributed objects of education voucher should be these students who have participated in the National College 
Entrance Examination in their place of domicile, filled the intention for full-time office-based national higher vocational education institutions approved and established by government sectors when they fill volunteer test, and have been enrolled officially. If the students choose to enter higher vocational colleges for study, they will submit education voucher. According to all the education vouchers handed in by students in the enrollment year, colleges should receive the financial subsidies that correspond to the number of students from the education commission and financial sectors. If the students choose to study in non-higher vocational colleges or go abroad for further study, the education vouchers will be invalid and forbidden for sale.

\section{B. Distribution and Recycling}

Education vouchers should be managed in a way of centralization and uniformly made by Ministry of Education and administrative department for education of provincial governments, and should be specifically distributed by the administrative department for education at city and county level according to the number of students who participate in the National College Entrance Examination, their grades and their intention for colleges. After the students are enrolled by higher vocational college, they can hold the effective Letter of Admission to the administrative department for education of origin of students to receive education vouchers, and submit the vouchers to the college when paying fees at register. For these students who have not got further study after the examination but have the right to receive education vouchers, they should also receive education vouchers from the administrative department for education at city and county level within the specified time and keep properly. After working for a certain period, when they prepare to continue to receive higher vocational education, they can register and fill the intention for colleges at the administrative department for education in their working place. When the intended college has remaining opportunity for students to apply for within the plan in the current year, the students can be enrolled. However, the college has no additional opportunity for students to apply for; these students can apply for other higher vocational colleges or enter the colleges for another year.

After registration, and collection of education vouchers, higher vocational colleges will concentrate the vouchers on education authorities for redeem the financial funds. According to the number of education vouchers and students' household register type, the provincial education authorities will directly allocate funds to the students in this province. In terms of students who study after working across the province, the provincial education authorities will submit the relevant information to the Ministry of Education, and the Ministry of Education will solve the inter-provincial financial fund allocation together with financial sector.

\section{Guarantee and Supervision}

If the education voucher system of vocational education cannot be effectively implemented, the financial appropriation of higher vocational colleges must be guaranteed. First: the implementation of this education voucher system will inevitably lead to a large fluctuation in the number of student enrollment in vocational education in the early stage of implementation. The education vouchers ensure that students have the qualifications for admission for a long period of time, so those students from poorer families must choose to work first, and then choose the time for admission based on the work situation. This will result in a situation in which the financial appropriation presents insufficient input in the former stage but abundant investment in the later stage, so local governments must adopt the form of withdrawing vocational education deposit annually to ensure that the annual education vouchers of vocational education are fully cashed. Second, the education voucher of vocational education has no fixed face value, and the amount of financial appropriation for vocational education in various provinces is different. Therefore, it is inevitable that the use of education vouchers in different years and different regions represent the different actual amount of funds. Therefore, the Ministry of Education must coordinate the provincial education authorities; establish corresponding organizations and specialized staff to be responsible for the distribution, use and audit of education vouchers, so as to avoid the credit problems caused by the use of education vouchers.

In order to implement the education voucher system in an open, fair and equitable manner, the education administration must promptly announce the distribution and use of education voucher to the whole society. This will not only protect the public's right to know, but also enable higher vocational colleges with good school quality and high student acceptance to get more exposure opportunities, and also prevent some vocational colleges from cheating the number of education vouchers they receive in order to recruit students. It helps the higher vocational colleges to form a healthy competition, thus realizing the entry and exit of the higher vocational colleges.

\section{CONCLUSION}

The education voucher system, with its applied range from common high education to basic education and its purpose from fund subsidies to the realization of educational equity, has always been a more controversial way of education reform. However, as a admission certificate to guarantee higher vocational education, the education voucher of vocational education is still a creative measure, which conforms to the lifelong characteristics of vocational education, is in line with the general trend of labor mobility in urbanization transformation in China, accords with the competitive requirements of the education industry, and is also a all-round deepening of the comprehensive reform in the field of education. Its practice is of great significance to the reform of higher vocational education in China. Under the influence of the education voucher system, the traditional regional-divided public finance expenditure model of higher education has changed to a modern, mobile and nationally unified finance expenditure form, thus improving the overall quality of higher vocational education and benefiting the entire society ultimately. In the future, we can also integrate such education vouchers or education accounts into various 
types of grants and scholarships, so as to reduce administrative costs and to play an obvious role in promoting fair education, enhancing the development of higher vocational colleges, improving public finance efficiency, and facilitating the competition of higher vocational education.

\section{REFERENCES}

[1] Song Xiaoxia. Study on American Education Voucher and Its Enlightenment to China's Education [D]. Dalian: Liaoning Normal University, 2009: 11-22. 宋晓霞. 美国教育券研究及对我国教育的 启示 [D]. 大连: 辽宁师范大学, 2009: 11-22.

[2] Zhang Shizhou, Wang Tianyi. Analysis of China's Education Voucher Policy from the Perspective of Policy Transfer Theory [J]. Heilongjiang Researches on Higher Education, 2013, (8). 张世洲, 王天一.政策转移理论视角下的我国教育券政策探析 [J].黑龙江高 教研究, 2013, (8)

[3] Zhu Jiaxin. The Choice of Higher Education Investment System Based on Education Voucher Theory [J]. China National Conditions and Strength, 2016 (5). 朱佳金鍂. 基于教育券理论的高等教育投资制 度选择[J]. 中国国情国力，2016（5）. 